\title{
JUNG'S ALLEGED MADNESS: FROM MYTHOPOEIA TO MYTHOLOGISATION
}

\author{
QUENTIN SCHALLER
}

PHANÊS • VOLUME $2 \cdot 2019 \cdot$ PP. 1-27

https://doi.org/10.32724/phanes.2019.Schaller 


\begin{abstract}
The testimony Jung gave of his nekyia, published in Memories, was spread and amplified by his biographers, so that it became a story of Jung's morbidity, or madness. This story constitutes the 'positive perspective' of the legend of Jung's madness, of which the Freudocentric point of view constitutes the 'negative perspective'. This paper offers a new reading of the experience Jung began in 1913 - one opposed to the retrospective diagnoses it criticises - by reflecting on the understanding Jung had of his crisis, regarding the way he understood schizophrenia at that time. Thus, this study tries to show that the concerns Jung had of his mental state before the outbreak of the First World War logically stem from his understanding of schizophrenia as developed in Transformations and Symbols of the Libido: that the appearance of mythological motives to consciousness indicates a loosening of the phylogenetic layers of the unconscious and is thus a symptom of psychosis. By consciously dealing with these visions, Jung will come to some of the deepest insights of his lifework and to a new understanding of schizophrenia, as well as to insights concerning the role and place of mythological contents in the psyche.
\end{abstract}

\title{
KEYWORDS
}

Jung, psychosis, madness, schizophrenia, Liber Novus, mythopoeia, mythologisation, nekyia. 
ctober 1913. Jung is thirty-eight years old and has acquired
an international scientific reputation for his psychiatric
work, which particularly focuses on psychosis. He has a
private practice primarily frequented by a large group of often wealthy patients, and a model family, according to the Swiss customs at the time. He is travelling by train towards Schaffhausen and, going through a tunnel, he loses consciousness and is overwhelmed by a vision. This event, which made him fear he might 'do a schizophrenia' (Eliade 1952:233), is the prelude to a long crisis, to the Odyssean undertaking of a hero looking for his myth, his nekyia.

Jung describes this nekyia in his Black Books, and narrativises it in his Liber Novus, which was published in 2009. However, his closest disciples had long known about the experience and existence of Liber Novus (Toni Wolff and Tina Keller for example, as will be discussed later). The public learned about it in 1962, when Jung's Memories, Dreams, Reflectionswrongly viewed by many as his autobiography - came out. Since Liber Novus represents a new testimony of this time of crisis in Jung's life, a troubled and controversial chapter of the history of psychology has opened up again with its publication: Jung's alleged madness.

To this day, Jung's name is too often associated with mysticism and madness - his work appearing at any rate unscientific and his personality resembling a sort of narcissistic guru. This collective idea was born in the Freudian ranks as soon as the first signs of dissent appeared between the Viennese neurologist and the Swiss psychiatrist in 1911-1912.

This study does not intend to trace the history of Jung's pathologisation by his detractors. This manoeuvre, which seeks to discredit Jung's person and work, is well known today and discussed in several publications. What is discussed less often is the other aspect of the history of Jung's madness, the one propagated by his hagiographers and biographers, who based their retrospective diagnoses above all on the testimony reported in Memories. If Jung's pathologisation by his detractors represents the negative perspective of this story, this other aspect constitutes the positive one: the mythologisation of Jung's mythopoeic experience.

This study will thus handle the legend of Jung's madness from its positive perspective. A summary of the conceptualisation of schizophrenia in the first decade of the twentieth century, with a focus on Jung's place and contribution to this research, will first be made. The reflections Jung has in 1912 of Dementia Praecox, or schizophrenia, as he developed in his biggest work before his experience, Transformations and Symbols of the Libido, will be stressed, as this understanding of schizophrenia is still 
valid for him during the first part of his crisis, that is to say during the experience of the visions that came about between October, 1913, and the outbreak of the war on August 1 ${ }^{\text {st }}, 1914$. This review will help to capture, later in this paper, the way he understood what was happening to him at that time. A summary of the testimonies Jung gave of his nekyia will then be developed in order to determine what he was talking about in the most accurate way and to understand its reception. It will then be possible to examine the spreading of the story of Jung's crisis by hagiographers and biographers of Jung. It will become clear that such hagiographers and biographers went beyond the statements of Memories without questioning the text by making remote analyses and diagnoses of their subject of study - diagnoses the reliability of which need crucially to be questioned - diagnoses that, as will be discussed in this study, make no sense in this context. I will try to show that these biographies elaborated a mythology of Jung's pathology by reading the testimony he made of his experience beyond the limits originally set. A new reading of Jung's nekyia, of his 'experience of madness', will then be proposed, to show that, if Jung deeply engaged with the question of madness during his experience, to the point that he feared for his mental health, he did not undergo the experience of schizophrenia. Indeed, it is the understanding of schizophrenia he had at the time that made him fear this possibility, an understanding that changed significantly as he came to some of the deepest insights of his lifework during his experience.

\section{MADNESS IN THE EASTERN WORLD AND ITS NOSOLOGICAL CLASSIFICATIONS}

In the course of the nineteenth century, psychological research in its broader sense switched from the field of philosophy to psychiatry, passing through neurology. Correspondingly, in a scientific perspective, madness became medically conceptualised as psychosis - and thus as a disease - and its nosological classification was constantly adjusted within this category at the end of the nineteenth and beginning of the twentieth century. I will very briefly summarise the development of the psychiatric conceptualisation of madness. One can find a laudably detailed overview, partly focusing on Bleuler's and Jung's works, in Michael Escamilla's Bleuler, Jung, and the Creation of Schizophrenias (Escamilla 2016).

In 1896, Emil Kraepelin creates a new disease entity, 'Dementia Praecox' (Escamilla 2016:49), in the fifth edition of his Psychiatrie: Ein Lehrbuch für Studirende und Aerzte (Kraepelin 1896), then expanded in 
the sixth edition (1899). There, Kraepelin differentiates the psychoses between Dementia Praecox and 'manic-depressive insanity'. He describes Dementia Praecox as a 'progressive mental deterioration' appearing in earlier life (cited in Escamilla 2016:45), thus grouping 'together into one presumed disease entity several previously described forms of insanity: hebephrenia, "the catatonia of Kahlbaum", and "certain forms of paranoia which undergo early deterioration"" (ibid:44). Another entity is isolated (without being clearly cut off from Dementia Praecox) on the psychotic spectrum at this time: paranoia, to which Eugen Bleuler devotes a work in 1906 (Bleuler 1906) and which differs from Dementia Praecox because of the prominence of profound delusions. There, Bleuler distinguishes 'the insane' (the term is used ten times in the book to qualify the idea or person of the paranoiacs - thus furnishing the supposed link between insanity and psychosis) from the obsessive, hysterical and intellectually limited personalities (Bleuler 1906:108,115). The term schizophrenia was coined in 1908 by Eugen Bleuler, as he was giving a lecture at a meeting of the German Psychiatric Association in Berlin. In a paper published the same year, he explains that the syndrome is neither a real dementia nor necessarily precocious, and that he will thus replace Kraepelin's term 'Dementia Praecox' with the word 'schizophrenia', as the latter best describes the principal symptom of the syndrome: the splitting of psychic functioning (Bleuler 1908:436).

In 1911, Bleuler publishes his work Dementia Praecox oder die Gruppe der Schizophrenien and departs from Kraepelin's biological approach by adopting a psychological one, without giving a final conclusion on the aetiology of schizophrenia. He reduces Kraepelin's view of seven pathognomonic symptoms to only two, keeping the incoherence of the thought (neologisms, stereotypies) and the absence of emotions, and differentiates five 'undergroups' (second section of the book) of these endogenic psychotic processes: paranoia, catatonia, hebephrenia, schizophrenia simplex and 'special groups' (Bleuler 1911).

\section{JUNG'S THOUGHT ON MADNESS UNTIL 1912}

I will consider the evolution of Jung's thought on schizophrenia beginning from his paper The Content of the Psychoses (Jung 1908). Similar to Bleuler, Jung adopts a psychological approach in his study of the mental disease and tries to sketch out a psychology of what he still calls 'Dementia Praecox', though criticizing the term for the same reasons given by his mentor (Jung 1908:\$330). While analysing the associations of some 
patients, Jung finds meanings in their delusions that indicate the presence of an inner world functioning on its own, which is incomprehensible for others, because it has broken away from the outer reality (ibid:§383). Hence, he discovers, for example, a rich inner life that nobody suspected in an apparently apathetic patient (ibid). Jung concludes that the inner life, which, by common sense, is called 'fantasy', becomes 'reality' to the mentally ill. Meanwhile, the exterior world, normally understood as reality, becomes a distant dream (ibid: $\$ 385$ ).

In the first part of Transformations and Symbols of the Libido, Jung distinguishes two types of thinking: the directed thinking, rational and logical, directed towards the external world (with adaptation purposes), and the non-directed thinking, or fantasy, working through images and feelings and turned away from the outside reality, towards the inner world, thus producing what Jung later calls an introversion of the libido (Jung 1912b: 'Concerning the Two Types of Thinking'; CW5:§§4-46). By the characterisation of these two kinds of thinking, Jung groups together different thought processes into the non-directed thinking: those of the socalled primitives and of ancient man (found in mythology for example), those of children, those found in dreams and those found in delusions of the mentally ill. It is interesting to note here that these reflections imply a continuum on which both schizophrenic processes (or what he personally termed at that time 'introversion neurosis'; Jung 1912:50, n.2) and the fantasies of a sane psyche are to be found: morbid delusions and sane fantasies belong on the same spectrum. He then postulates the ontogenetic recapitulation of phylogeny in man's psychology (Jung 1912b:28), and so the existence of an impersonal layer of the unconscious. Therefore, he understands schizophrenia as being a loosening of the phylogenetic layer of the unconscious. The non-directed thinking, turning the individual towards his inner world (introversion), produces a regression. This regression reaches first the personal, infantile material of the unconscious and, in case of an intensification of the regression due to a psychosis or violent (and thus morbid, pathological) repression, will reach the historical layers of the unconscious (the infancy of humanity) and activate their archaic contents (ibid:37). Based on Freud's theory, Jung even explains, for example, the 'hallucinating clearness' of some dreams by a regression of the thought excitation reaching the perceptive system of the individual (ibid:26).

In Transformations and Symbols of the Libido, Jung does not diagnose the object of his study, Miss Miller, but only analyses her productions. Yet, at the beginning of the chapter, 'The Hymn of Creation', Jung compares 
the state of introversion of Miss Miller with Dementia Praecox and even describes it the way he described Dementia Praecox in his 1908 article:

after the life of the cities, with their many impressions, had absorbed her interest [...], she breathed freely upon the ocean, and after so many external impressions, became engrossed wholly in the internal with intentional abstraction from the surroundings, so that things lost their reality and dreams became truth (Jung 1912b:50).

In a corresponding footnote, he relativises the poor prognosis of Dementia Praecox, explaining this latter by the theorisation, or classification, of the illness by psychiatrists who can only observe the most serious cases. He then compares Dementia Praecox with Bleuler's schizophrenia and Janet's psychasthenia (a mental illness in which thoughts, emotions, and representations intrude upon consciousness, leading to a dissociation, and in certain cases to a duplication of the personality), implying that Miss Miller's case (which he understands as a repression of an erotic tendency, later transformed into a creative piece of writing) belongs to these numerous less serious cases, which do not require psychiatric internment (Jung 1912b:50n.2). Thus, he confirms his view of a 'normal' or non-morbid state of introversion that produces a reversal of inner and outer reality. The main difference between sanity and madness lies here in either maintaining or losing contact with external reality (Jung 1912b:50;141).

In the second part of Transformations and Symbols of the Libido, Jung redefines the Freudian theory oflibido as not applying to the psychology of Dementia Praecox: he explains that the absolute loss of 'fonction du réel' (Janet) cannot be attributed to the loss only of sexual functions of the psyche, since reality is not a sexual function (Jung 1912b:141f.). On the contrary, in the case of most neuroses, the sexual part of the libido is repressed and leads to a regression in this domain, but the psychological adaptation to external reality is guaranteed through a non-sexual part of the libido. Jung then distinguishes hysteria and schizophrenia by writing that the schizophrenic 'is more than autoerotic, he builds up an intra-psychic equivalent for reality...' (Jung 1912b:152). These considerations lead him to adopt an energetic conception of the libido.

Continuing on with these reflections, Jung postulates that the nonsexual libido that is withdrawn from reality in schizophrenia, which is normally used by the psyche for adaptation purposes, causes the regression 
to an earlier, and so archaic, mode of adaptation, which means the use of non-directed thinking, taken by the mentally ill at face-value: it is the symbolic life, in which the symbol is considered as applicable, or valid, for external reality. This implies the existence of two kinds of truths and realities: the 'actual truth'—or reality—and the 'psychological truth'—or reality - (where the symbol belongs), two realities with their own kinds of contents and modes of apperception (Jung 1912b:262).

Jung then shifts his clinical language to a mythological one, or a graphic one, a method of amplification which he uses to analyse the psychological processes found in a particular transformation of the libido: the introversion which leads to a transformation of personality, which he describes as a journey found in mythology under the name of nekyia.

In the second part of Transformations and Symbols of the Libido, Jung postulates a necessary neurotic condition as the basis for the descent into one's own depths (the introversion): the child, separating himself from the mother (the symbolic mother, which is his biological mother as well as his unconscious) to meet the exterior life, will later as an adult feel a sense of disunity with himself (Jung uses in the German version 'uneins mit sich selbst' (Jung 1912a:359), literally 'not one with himself', divided, which is not translated into the English version): he is separated from his unconscious. Hence, he yearns for death, for the return to the mother, and so descends into his own depths: this movement introduces the catabasis.

After the descent comes the time for the fight with the devouring terrible mother, with the paralysing yearning for the depths (see chapter, 'The Battle for the Deliverance from the Mother'). The only way to overcome it is to sacrifice this longing, that is to say the infantile personality (see chapter entitled 'The Sacrifice'):

and this is the dangerous moment, in which the decision takes place between annihilation and new life. If the libido remains arrested in the wonder kingdom of the inner world, then the man has become for the world above a phantom, then he is practically dead or desperately ill (Jung 1912b:330)

How not to think about the clinical picture of catatonia at the reading of this sentence! On the other hand, if the individual achieves the sacrifice, then his personality will be transformed and the anabasis will take placetransformed in religious yearning.

These are the big lines of Jung's thought on schizophrenia and its place in the nekyia at the time of the beginning of his crisis. 


\section{JUNG'S TESTIMONY ON HIS 'NEKYIA'}

Let us now concentrate on the crisis Jung endured from 1913 on. I will not enter in detail concerning what he later called his 'experience of the unconscious' as his testimonies dealing with it are known-I will settle on summarising them. The first written testimony of Jung's nekyia which must be mentioned is the seminar he gave in 1925 (Jung 1989) - this event represents also the first and only time Jung spoke of his experience in public. However, it was not published until 1989 and the fifty copies of the notes on the seminar were only distributed to some of Jung's disciples (Shamdasani 2012:xxi). But, if the first depiction of Jung's nekyia is to be found in this seminar given in 1925, there is, to my knowledge, no correspondence between Jung's disciples, nor are there any writings, proving and detailing a spreading of this story. As it has not been published before 1989, and the first biographies of Jung relating to his nekyia date from the early 1960s (as will be discussed later in this paper), one cannot consider the testimony contained in this seminar as the main source for the disseminating of the story of Jung's madness among his hagiographers and biographers. The first publication relating to this experience is an interview that Jung gave to Mircea Eliade for the Journal Combat in 1952, but only available to the German- and English-speaking public from 1977, as the article is published, translated in English, in C.G. Jung Speaking (Eliade 1952)1. Memories is thus the first detailed story of Jung's nekyia and can be considered as the main source for the spreading of the story of Jung's morbidity: until the middle of the 1990s, all of Jung biographers based their analyses of this episode on the testimony from Memories $^{2}$.

In this seminar, Jung shares some of the big visions and events which punctuated his nekyia, and discusses the similarities between his mental state at the time and the processes occurring in Dementia Praecox. In the fifth lecture, Jung narrates his vision from October, 1913, and the argument with the voice of his Anima telling him he was doing art (Jung 1989:24). The vision from October, 1913, is again discussed in the sixth lecture, along with his first 'conscious descent within the unconscious' (Jung 1989:51) and the dream of Siegfried's murder (Jung 1989:53) which is again addressed in the seventh lecture (Jung 1989:61). Then the

${ }^{1}$ This interview was given at the 1952 Eranos Conference. Jung discusses there his recently published book Answer to Job, his psychological understanding of alchemy, the reality of religious experience, his concept of collective unconscious and his nekyia.

${ }^{2}$ Until the publication of Sonu Shamdasani's 'Memories, Dreams, Omissions' (1995). 
lectures 8, 11 and 12 discuss the content of the first part of Liber Novus, 'Liber Primus': the encounter with Elijah and Salome and the occurrences in the 'Mysterium'.

According to the narration of Memories (chapter, 'Confrontation with the Unconscious'), at the end of 1912, Jung had important dreams that meant for him a tremendous, or - as he put it - 'unusual' animation of the unconscious (Jung 1962b:172), which made him ask himself whether he was experiencing a mental disorder (Jung 1962b:173). From October, 1913, onward, a multitude of visions poured through him, most of them transcribed in the Black Books and in Liber Novus. As the vision of the flooding of Europe repeated itself in December, 1913, he asked himself whether he was not 'doing a schizophrenia' (as related in his interview to Mircea Eliade). From December $12^{\text {th }}$ of the same year, Jung begins his 'confrontation with the unconscious'. In Memories, he speaks of the panic which manifested to him as visions with a clear mythological content, imposing themselves on his consciousness (ibid). He writes on the inner world he was discovering:

It is of course ironical that I, a psychiatrist, should at almost every step of my experiment have run into the same psychic material which is the stuff of psychosis and is found in the insane. This is the fund of unconscious images which fatally confuse the mental patient. But it is also the matrix of a mythopoeic imagination which has vanished from our rational age (Jung 1962b:188).

In Memories, Jung simply states that he feared a psychosis until the war broke out in 1914. Strictly speaking he does not say he experienced psychosis, but only the same material he observed in the psychotic delusions of his patients: the mythological images. In 1934, at the Eranos conference, he compared the symbolic process, i.e., the practice of active imagination, with a 'voluntarily induced psychosis', in which the threshold of consciousness is involuntarily overwhelmed by the contents of the unconscious (Jung 1935:224, author's translation). In Mysterium Coniunctionis, he explains that if 'the patient can do active imagination and shape out his fantasies, and there are no suspicious incidents, then there is as a rule no longer any serious danger' and that active imagination 'amounts to an anticipated psychosis' (Jung 1955-1956:§755).

Answering a question about his visions in the 1925 Seminar, Jung explains: 
there was a great deal of affect with them. As I could see no possible application to be made of them, I thought to myself, "If this means anything, it means that I am hopelessly off." I had the feeling that I was an over-compensated psychosis, and from this feeling I was not released till August 1st, 1914 (Jung 1989:48).

Here, Jung expresses the fear he had after this vision, concerning his mental state, but also clearly denies a potential psychosis. On August $1^{\text {st }}, 1914$, Jung learns about the outbreak of the world war and understands that the visions he had, the flooding of Europe, the freezing cold on Europe, etc., did not concern his psychological state but foreshadowed the collective events, which came to pass in Europe-that these 'big dreams' originated from the impersonal layers of the unconscious and so had - also - a collective value; or, as he will later say, a prophetic value, understanding the atemporal and aspatial properties of the unconscious.

\section{THE MYTHOLOGISATION OF JUNG'S 'NEKYIA'}

The first biographical writings which relay the story of Jung's 'confrontation with the unconscious', and therefore of his proximity to madness, were, with some exemptions, produced by Jungian scholars from a non-critical perspective and are thus hagiographers. The myth of Jung's madness was first propagated through the writings of his disciples and then through those of professional biographers that took Memories as an autobiographical work (although it has been proved not to be-see Shamdasani 1995 and Maillard 2002) and blindly relied on them to make and deliver their own retrospective diagnoses of their subject. These are certainly not as polemical as Jung's pathologisations which were spread through his critics' writings, but their relevance and accuracy is just as questionable.

Also, the handling of the main source of these biographies is clearly problematic. The truth of Memories is not questioned, as concerning the supposedly autobiographical nature of the work as well as the integrity and origin of its statements. I propose to review some important works which spread the story of Jung's madness in its positive perspective.

In 1964, D.W. Winnicott writes a review of Jung's Memories ('Memories, dreams, reflections by C. G. Jung'). There, he diagnoses Jung with infantile schizophrenia, a psychotic disease and a psychotic 
depression, when the subject was three years old (Sedgwick 2009:82). The catalytic role of Memories should be noted here, thus its shift to an object of projection for Winnicott (see Sedgwick 2009 and Meredith-Owen 2012), and Jung's assertion concerning the non-pathological nature of the dissociation he expresses through the conception of the personalities 1 and 2 (Jung 1962b:45).

Henri Ellenberger continues the story in 1970 with the chapter he devotes to Jung in his monumental Discovery of the Unconscious. He identifies the crisis Jung passed through as the 'creative illness' he had postulated in 1964 (Ellenberger 1970:672; Ellenberger 1964). Later, in 1993, Ellenberger identifies Jung's 'creative illness' as a 'protracted neurotic disorder' (Shamdasani 2005:69).

Barbara Hannah devotes a 'Biographical Memoir' to the Swiss psychiatrist in 1976. Hannah simply regards Jung's experience of the unconscious as a depression, which is hardly debatable (depression being understood, in Jungian psychology, as an important introversion of the libido, and so as a regressive psychical movement), and relays Jung's word concerning his fear of 'making a psychosis' (Hannah 1976:107).

In 1976 and 1977, two writings, which Alan Elms rightfully identifies as pathographies of Jung (Elms 2005:334-335), were published: C.G. Jung: The Haunted Prophet, by Paul Stern (1976), and George Atwood's and Robert Stolorow's article 'Metapsychology, Reification and the Representational World of C.G. Jung' (1977). Paul Stern, largely relying on Memories, and giving unsourced details which could 'derive from Zurich gossip', diagnoses Jung as being 'semi-psychotic' (Elms 2005:334, 335; see also Stern 1976:156; Shamdasani 2005:73) and suffering from a 'narcissistic personality disorder'. Atwood and Stolorow, in turn, point out, above all, 'anxieties of self dissolution' and reach a similar conclusion, mentioning a narcissistic pathology — as did Richard Noll (1994 and 1997; noted in Elms 2005:335).

In 1985, Gerhard Wehr published his work Jung: Leben, Werk, Wirkung, in which, mainly drawing again on Memories, Jung is diagnosed with a "borderline case" [...] on the threshold between neurosis and psychosis' (Wehr 1985:160, author's translation). This analysis, knowing that Wehr takes Jung's account of his nekyia at his word, is completely justified and logical:

To the extent that I managed to translate the emotions into images that is to say, to find the images which were concealed in the emotions I was inwardly calmed and reassured. Had I left 
those images hidden in the emotions, I might have been torn to pieces by them. There is a chance that I might have succeeded in splitting them off; but in that case I would inexorably have fallen into a neurosis and so been ultimately destroyed by them anyhow (Jung 1962b:177).

This diagnosis will be repeated in subsequent biographical studies, like Spillmann's and Strubel's (2010:127, noted in Falzeder 2014:20).

Jeffrey Satinover devoted an article to Jung in 1986. Citing numerous authors who tried a retrospective analysis of Jung, he states here that one finds a guiding thread in all their diagnoses: 'Jung's psychopathology was not neurotic - it was narcissistic (Homans 1979), or "trans-neurotic" (Wolf 1984), or schizophrenic (Stern 1976), or childhood-schizophrenic (Winnicott 1964) - that is, in general terms, it involved "early and deep fragmentations of one's self" (Ticho 1982:861) (Satinover 1986:415).

In 1988, Linda Donn collected interviews she conducted with some close relatives of Jung. In them, Liliane Frey expresses that Jung 'was very near psychosis. He didn't know how it would turn out' (Donn 1988:179). Franz Jung states also here that his father 'placed a gun in his nightstand, and said that when he could bear it no longer he would shoot himself', and that Jung thought he 'might fall forever into the void'. He also describes his father as 'a man who [...] painted pictures of circles all day' (ibid:172).

I will not elaborate on the biography Deirdre Bair devoted to Jung in 2003, as the work has been already analysed in detail (Shamdasani 2005:87ff.). But because of its reception, we shall repeat that the book contributed to the mythologisation of Jung's madness, as the author considers his visions to be psychotic (Bair 2003:245, 290).

The list of works by analysts, historians, and more or less professional biographers, that contribute to the propagation of the legend of Jung's madness is still long. Most of them deliver the kind of retrospective diagnoses I have just discussed in this chapter by relying, above all, and incorrectly, on the narration of Jung's experience as written in his Memories. But the issue raised here does not only concern the retrospective character of the diagnoses (a problematic character regarding its reliability and scientific rigour), but the essence of diagnosis itself. This is very clear while reading the innermost document relating to this period, Liber Novus: in it, everything indicates that Jung did not consider his experience at that time in terms of 'diving into the unconscious'. As the terminology of Liber Novus shows, Jung completely put aside the psychiatric nosology at that time, for the duration of his experience at least-including the 
notion of the 'unconscious'. Thus, there was probably no question of 'the unconscious' during his experience, ${ }^{3}$ but rather of 'the spirit of the depths', 'the chaos', 'the void', 'the pleroma', etc. It is thus nonsense to try to classify Jung's crisis psychiatrically: what he recounts is a living symbolic and prophetic experience, which has nothing to do with any kind of psychiatric framework or rigid scientific conception. He tells the story of his meeting, of his engagement with madness, which allowed for a deeply creative movement: Liber Novus contains far less reflections on 'madnesses', which could be linked to psychosis or neurosis, than reflections on 'divine madness', which is Philemon's magic: an interior, irrational access to a different kind of knowledge.

The reception of Jung's testimony by his biographers is thus a 'story meant to be repeated mechanically, almost unknowingly' (Shamdasani and Borch-Jacobsen 2012:12), a dehistoricised story, a legend whose function is 'evidently not to adequately represent the past, but to ritually celebrate a timeless miracle' (in Shamdasani and Borch-Jacobsen 2006:26) ${ }^{4}$. (On the particular dehistoricisation found in Memories, see Shamdasani 1995:41.) It is a legend which crystallises logically on the mythologisation of the period of Jung's 'confrontation with the unconscious', the period of his meeting with madness, as he very famously said:

The years when I was pursuing my inner images were the most important in my life - in them everything essential was decided. It all began then; the later details are only supplements and clarifications of the material that burst forth from the unconscious, and at first swamped me. It was the prima materia for a lifetime's work (Jung 1962b:199).

\section{A NEW READING OF JUNG'S EXPERIENCE}

So let us take a completely different look at what happened for Jung at that time by asking how he could understand the crisis and the visions he was experiencing regarding the comprehension he had of the psyche, and particularly of schizophrenia, in 1913.

Towards the end of writing Transformations and Symbols of the Libido, Jung asked himself the question that initiated his own

\footnotetext{
${ }^{3}$ I wish to thank Sonu Shamdasani for this remark.

${ }^{4}$ Author's translation. This sentence does not appear in the English version of the book.
} 
transformation, the question of the nature of what he had just written and the existence of the myth of his life - this myth relating to the meaning of one's life (Jung 1962a:10) ${ }^{5}$. The time of crisis, his nekyia, is a journey of the search for meaning, of the search for his life's myth. By seeing that this latter, narrativised in Liber Novus, is intimately linked to the contents and the process of writing Transformations and Symbols of the Libido (and so to a certain comprehension of schizophrenia, which will come to change during Jung's own experience), one can understand why Jung was at first puzzled when mythological visions and autonomous contents of the unconscious poured over him. But not only were they mythological, they also repeated some contents and processes he found active in Miss Miller, a case he compared with some aspects of Dementia Praecox, as I showed earlier.

In Transformations and Symbols of the Libido, Jung exposes a neurotic condition prior to the catabasis, an 'Uneinssein mit sich selber'-a division within oneself, a nostalgia of the mother, of the depths. A condition often happening in the second part of life: 'In the first half of life, [the libido's] will is for growth, in the second half of life it hints, softly at first, and then audibly, at its will for death' (Jung 1912b:480). These two elements, the metanoia and the feeling of division (I deliberately avoid the term 'dissociation') are to be found from the beginning of Liber Novus. On November 14 ${ }^{\text {th }}, 1913$, Jung writes in his Black Books: 'On the second night I called out to my soul: "I am weary, my soul, my wandering has lasted too long, my search for myself outside of myself...I wandered for many years, so long that I forgot that I possessed a soul"' (Jung 2009:233).

On December 17 ${ }^{\text {th }}, 1913$ : 'So I cried full of anger, "But then my indignation must also come from you, and in me you are indignant against yourself." My soul then spoke the ambiguous words: "That is civil war"'. The corresponding footnote indicates that the I asks then to the soul: 'Are you neurotic? Are we neurotic?' (Jung 2009:241).

Jung interprets the moment of this introversion (the metanoia) in the second layer of the narration, written between the summer of 1914 and 1915. In the chapter, 'Refinding the Soul'-whose title itself is very relevant in the context of this paper-Jung wrote:

When I had the vision of the flood in October of the year 1913, it happened at a time that was significant for me as a man. At that

\footnotetext{
${ }^{5}$ The often used expression 'personal myth' comes from the mistranslation, in the English version of Memories, Dreams, Reflections, of the expression used by Jung in the original German version : 'der Mythus meines Lebens', i.e. 'the myth of my life'.
} 
time, in the fortieth year of my life, I had achieved everything that I had wished for myself. I had achieved honor, power, wealth, knowledge, and every human happiness. Then my desire for the increase of these trappings ceased, the desire ebbed from me and horror came over me. The vision of the flood seized me and I felt the spirit of the depths, but I did not understand him. Yet he drove me on with unbearable inner longing (Jung 2009:231).

About this flood, which Jung saw several times in vision and which is central in his testimony of his experience, of his questioning of his mental health and on the interpretation of these events as prophetic, he writes in Transformations and Symbols of the Libido, relying for example on Indian mythology: 'Through Vishnu's ecstasy came the flood on the world (engulfment through introversion, which symbolizes the danger of entering the mother)' (Jung 1912b:330). Or: 'This motive explains the meaning of the "Deluge"; the maternal sea is also the devouring mother. The fantasy of the world conflagration, of the cataclysmic end of the world in general, is nothing but a mythological projection of a personal individual will for death' (Jung 1912b:481).

In Transformations and Symbols of the Libido, Jung wrote: 'This means, mythologically, that the sun is devoured by the serpent of the night, the treasure is concealed and guarded by the dragon: substitution of a present mode of adaptation by an infantile mode, which is represented by the corresponding symptoms' (Jung 1912b:421). In Liber Novus, in the chapter, 'Descent into Hell in the Future': 'In the deepest reach of the stream shines a red sun, radiating through the dark water. There I see - and a terror seizes me - small serpents on the dark rock walls, striving toward the depths, where the sun shines. A thousand serpents crowd around, veiling the sun. Deep night falls' (Jung 2009:237).

The 'terror' here is quite understandable on several levels: of course we can imagine this emotion overwhelming him in advance of such a vision; but the vision is also very close to a mythological motive he had analysed a few years before in a case of morbid introversion.

In Liber Primus, the meeting with Elijah and Salome happens in the crater where they are living, in the Mysterium. There, the narrator finally accepts his descent in the chapter, 'Resolution', which enables him, after his 'crucifixion', to enter the visions following in Liber Secundus. In Transformations, one can read: 'The crater symbolizes [...] the mother; the serpent the resistance defending her' (Jung 1912b:476). However: 
he [the hero] is at war with himself [uneins mit sich selbst], and, therefore, the descent and the end appear to him as the malicious inventions of the mother of death, who in this way wishes to draw him to herself. The mysteries [Das Mysterium], however, consolingly promise that there is no contradiction or disharmony when life is changed into death ${ }^{6}$ (ibid:419).

A fundamental teaching the narrator receives from Elijah concerns the objectivity of the unconscious and the element of reality of the contents of the unconscious. Jung already wrote about the 'other reality', the psychological reality, in Transformations, as well as about the objectivity of the unconscious ${ }^{7}$ - which means he was conscious of these facts before the instruction through Elijah. Yet, this teaching seems new for the narrator of Liber Novus:

I: You are symbols and Mary is a symbol. I am simply too confused to see through you now.

E: You may call us symbols for the same reason that you can also call your fellow men symbols, if you wish to. But we are just as real as your fellow men. You invalidate nothing and solve nothing by calling us symbols.

I: You plunge me into a terrible confusion. Do you wish to be real?

E: We are certainly what you call real. Here we are, and you have to accept us. The choice is yours. (Jung 2009:249).

In Transformations, Jung wrote:

That the dragon is only an artifice is a useful and delightfully rationalistic conceit, which is most significant for that period. In this way the dismal gods were effectively vulgarized. The schizophrenic insane readily make use of this mechanism, in order to depreciate efficient personalities (Jung 1912b:403).

One understands that the conversation between Elijah and the narrator just quoted seeks exactly the opposite purpose of the apotropaic movement described here in Transformations, so that the conversation can be seen, on another level, as having auto-suggestive purposes-

${ }^{6}$ See original terminology, set here in square brackets (Jung 1912a: 359).

${ }^{7}$ As discussed earlier. 
which recalls those used by Helene Preiswerk, as Jung analysed in On the Psychology and Pathology of So-Called Occult Phenomena (Jung 1902).

Apart from the similarities of the motives and processes found in Miss Miller's case in Transformations, and in Jung's case in Liber Novus, one should consider the realisation of the objectivity of the psyche and, therefore, of the reality of the unconscious contents, as one of Jung's fundamental discoveries during this time - as one knows about the importance of this question in Jung's life work. And the process of this realisation seems quite clear: as the objectivity of the unconscious contents was a fact he was intellectually aware of during the writing of Transformations, it became a fact he livingly experienced at the end of 1913, and which seemed to unsettle him quite significantly.

\section{JUNG'S PROFESSIONAL AND PERSONAL ISOLATION}

Another biographical question needs to be raised in this context: Jung's professional and personal isolation. The narration of Memories highlights this isolation and links it with Jung's concerns about his mental health at the time. As the status of Memories is here re-evaluated, one should consider this issue anew, regarding important facts and versions removed from Memories and thus absent from the works representing the story of Jung's madness, as addressed earlier in this study.

Concerning Jung's professional isolation at the time, ${ }^{8}$ Ellenberger considers this to be 'exaggerated', a statement which he repeats several times in regard to some assertions Jung made about this period in his life, because the psychiatrist 'had kept a few disciples, and a small Jungian group was founded in 1916 in Zurich under the name of Psychologischer Club' (1970:673). Maeder stated that he was very close with Jung at that time and considered himself to be one of his disciples until 1928. Furthermore, his resignation as Privatdozent in April 1914-which contributed to Jung's professional isolation-seems to have come about not only due to the fact that his 'experience and experiments with the unconscious had brought [his] intellectual activity to a standstill' and that he found it 'unfair to continue teaching young students when [his] own intellectual situation was nothing but a mass of doubts' (Jung 1962b:193). As a matter of fact, Ellenberger reports that Maeder told him that Jung quit his post at the University of Zurich, because the university 'refused to grant him the title of Professor' (1970:739, n.38). In the Protocols, Jung

${ }^{8}$ See Jung (1962b:167): 'After the break with Freud, all my friends and acquaintances dropped away...'. 
gives a reason for his demission which differs from both the explications of Memories and those of Maeder. He there states that he quite consciously sacrificed his academic career and was at the time ready to assume every risk concerning the huge process happening in him: there is thus a clear prioritisation of the inner experience over the scientific work and career.

On the $10^{\text {th }}$ of July, 1914, the Zurich Psychoanalytical Society left the International Psychoanalytical Association and became the Association for Analytical Psychology, in which Jung was 'actively involved' (Shamdasani 2009:201). His scientific activity was profuse: he worked on some of his fundamental writings at that time, like his psychological typology ${ }^{9}$-as reflected in his correspondence with Hans Schmid (Jung 2013) and his communications at the Psychologischer Club - as well as some important texts (namely The Transcendent Function, 1957, and The Structure of the Unconscious, 1916 - the two talks upon which Adaptation, Individuation, Collectivity, 1970, is based). These works, because of their nature, their theoretical formulations and their systemisation, require a strong involvement of the directed thought, which is opposed to the non-directed thought (as mentioned earlier), which Jung used in the evenings during his visionary experience and which destabilised him so much. Furthermore, his weeks were busy with intense therapeutic activity, with on average of five to seven consultations per day, five days a week, between 1913 and 1914 (Shamdasani 2009:201). Jung also served in the military at the time, doing 248 days of service between 1913 and 1917; this was an activity which requires, as one can imagine, a certain amount of discipline and balance (Shamdasani 2009:201).

Hence, Jung's days were devoted to his family and professional activities, compensating, in an effort to find the right psychic balance, for the introversion of his visionary evenings (Shamdasani 2009:201). The professional isolation Jung addresses in Memories does not seem as unintentional as it appeared in the narration. However, Maeder emphasized that even if Jung kept relationships with his disciples and some colleagues, he was, between 1914 and 1919, 'extremely reserved and somewhat distrustful, even toward his most faithful disciples. None of them suspected the interior experience he was then undergoing' (Ellenberger 1970:673). One understands thus that Jung, even surrounded by a crowd, could have been plunged into loneliness at that time. But what about his personal isolation? Another figure of major importance supported him during this confusing time and gave him comfort in the solitude of his evenings: Toni Wolff.

${ }^{9}$ Later published in Jung (1921). 


\section{SOROR MYSTICA}

Toni Wolff's name does not appear in Memories, although Jung stressed the vital importance of her help during his crisis years, as evidenced in the 'Protocols of Aniela Jaffe's interviews with Jung for Memories, Dreams, Reflections'. This 'omission' is by no means insignificant. As Jung told Aniela Jaffé in these interviews, and as notably Barbara Hannah, Tina Keller and Liliane Frey explained, without Toni Wolff's help, Jung would undoubtedly not have been able to throw himself in the experience he began in 1913, or maybe he would not have come out unscathed (Healy 2017:127 and Swan 2006:503). For many, Toni Wolff, with her extraordinary intuition (which was one of her main gifts as an analyst), was able to accompany her patients in the world of the unconscious like no other, and thus for Jung she played the role of the Anima, of the Soror Mystica, so that some scholars consider her, in some sense, to have been Jung's analyst during this time (see Swan 2006:503, 506; Hannah 1976:118; Wehr 1985:171; for references regarding this discussion, see Healy 2017:349, n.78). And indeed, Jung explains in the Protocols that with the beginning of the relationship with Toni Wolff, he entered the great chaos of the unconscious. He also states there, contrarily as earlier certified by Barbara Hannah and Tina Keller, who reckoned that Wolff never had the ability to practice the method of active imagination and had 'difficulty to let her own images emerge' (Swan 2006:506; Hannah 1976:118f.), that Wolff entered a similar stream of images, which he thought he himself unintentionally triggered, and that both their interior experiences were in such a 'participation mystique', that it was a common stream and a common task. One understands thus the importance of the relationship and the level of intimacy he had with his former patient. Jung declared in this same interview that nobody could help him, and that he could speak of this experience with nobody else (not even with his wife, Emma) but Wolff, who also found herself completely disoriented in the same chaos as him.

Toni Wolff seems however to have also been a further help in this crisis. Jung explained the importance of the rational interpretation within the symbolic experience, which enables one to emerge from the chaos of images and not to allow oneself to be possessed by this chaos (Jung 1962b:192, 1929:§64). In this process of understanding, the young woman's help and skills were precious: she understood the depth of what he was going through and was 'recognizing and identifying elements in his visions that C.G. himself may have not seen' (Healy 2017:124). According 
to Jaffé, she helped him with the 'intellectual penetration of the world of psychic images' (Jaffé 1971:174; Healy 2017:124).

Another valuable testimony concerning Jung's therapeutic practice during this time of crisis comes from Tina Keller who was his patient between 1915 and 1924 (Swan 2006:493). She reported that her analysis began during Jung's confrontation with the unconscious - the year Jung began the drawings of Liber Novus - and therefore the book was often placed on an easel during the sessions, within sight of the patients (Swan 2006:501) and it helped him to explain his introspective method to his patients (Swan 2006:497). While the therapeutic work Tina Keller did with Toni Wolff (who served as her analyst between 1924 and 1928) was based upon the confrontation with the unconscious, the work she did with Jung prior to this aimed at reinforcing the ego (Swan 2006:498, 506) to 'withstand the impact of unconscious images', a psychological condition required for the exploration of the unconscious, of which Jung was aware at least from 1915.

\section{CONCLUSION}

In the 1925 Seminar, Jung explains that Transformations and Symbols of the Libido has to be read by taking into account its subjective aspect, as he had projected his unconscious material and his fantasy function onto Miss Miller's, also stating that 'the Psychology of the Unconscious can be taken as [him]self and [that] an analysis of it leads inevitably into an analysis of [his] own unconscious processes' (Jung 1989:28).

This means that the crisis of 1913 can be seen as a withdrawal of this projection and so a direct experience of the contents and processes he projected. This movement is really clear when one compares the symbolic contents and the psychological transformation described in the two books. Hence, by putting oneself into Jung's place at that time, one understands that between October, 1913, and August, 1914, he began to directly experience contents and processes he wrote about a few months before and compared to Dementia Praecox. As known from the understanding Jung had from schizophrenia after the writing of Transformations, which is that the emergence of mythological symbols in the psyche means a loosening of the phylogenetic layers of the unconscious, and is thus a symptom or an indication of schizophrenia, one can understand that he was confused and bewildered by the appearance of this kind of symbolism in his fantasies - which made him naturally question his mental health. Another interesting point is that, during this time, he could directly experience 
psychological facts and processes he intellectually understood during the work on Transformations and Symbols: the 'Uneinssein mit sich selber', the metanoia, the descent into one's own depths, the objectivity of the unconscious, and so the character of reality of its contents, among other things. It is the assimilation of this last point, the reality of the unconscious, that allowed the psychological process and the fantasies to continue after those transcribed in Liber Primus.

This is most probably the second reason why Jung was so startled during the first part of his experience: after observing in his own fantasies the type of contents he could see in the delusions of his schizophrenic patients a few years before, he then experienced, as he could also observe in his schizophrenic patients, the character of the unconscious and its contents, including their overwhelming power over the consciousness. Jung, talking about Elijah and Philemon in Memories, Dreams, Reflections, said:

Philemon and other figures of my fantasies brought home to me the crucial insight that there are things in the psyche which I do not produce, but which produce themselves and have their own life. Philemon represented a force which was not myself. In my fantasies I held conversations with him, and he said things which I had not consciously thought. For I observed clearly that it was he who spoke, not I. He said I treated thoughts as if I generated them myself, but in his view thoughts were like animals in the forest, or people in a room, or birds in the air, and added, "If you should see people in a room, you would not think that you had made those people, or that you were responsible for them." It was he who taught me psychic objectivity, the reality of the psyche (Jung 1962b:183).

These - the emerging of mythological visions and the direct experience of the reality of the soul-seem to be the two important elements which have unsettled him the most at the time. It is thus not surprising that these elements also permitted two of the biggest realisations he had during his experience and its interpretation, namely the fact that the apparition of mythological motives in the psyche is not a criterion of morbidity and can be dealt with consciously in the context of a work of transformation of the personality; and the reality of the soul itself.

To finish, let us return briefly to the 1925 Seminar, where Jung compares the vision he had in October, 1913, and the processes going on 
in Dementia Praecox - this applies also for the dream of the freezing cold descending on Europe, which repeated three times between June and July, 1914.

If I were a case of dementia praecox I would easily spread my dreams over the whole world and take it that the destruction of the world was indicated, whereas in reality all that might be indicated would be the destruction of my relation to the world. A person with dementia praecox wakes up one day to find that the world is dead and the doctor nothing but a ghost - he alone is alive and right. But in such cases there are always plenty of other symptoms present to prove the essential abnormality of the person. The more normal the individual, the more it can be assumed from such fantasies that some profound social disturbance actually is in progress, and at such times there are always many more than one person whose unconscious register the upset conditions (Jung 1989:47).

Then: 'So if I had been crazy, I could have preached the coming disaster like the man on the walls of Jerusalem' (Jung 1989:48).

This means that Jung controlled his experience at the time, in the sense that he dealt with the experience consciously: instead of preaching the coming disaster, he asked himself what these visions meant, tried to interpret them, and finally confronted himself consciously with the contents of the unconscious from December $12^{\text {th }}, 1913$, onward. Thus, he could understand that the crucial element regarding schizophrenia is not the appearance of mythological contents in the fantasies but the behaviour of the consciousness towards the contents of the unconscious, the integration of the unconscious contents preventing the overwhelming of the consciousness - as he will theorise in his texts written in 1916: Structure de l'inconscient and The transcendent function.

University of Strasbourg

quent.schaller@gmail.com

\section{REFERENCES}

Atwood, Georges E. and Robert D. Stolorow. 1977. 'Metapsychology, Reification and the Representational World of C. G. Jung.' International 
Review of Psycho-Analysis 4 (2): 197-214.

Bair, Deirdre. 2003. Jung: A Biography. New York: Little Brown.

Bleuler, Eugen. 1912[1906]. Affectivity, Suggestibility, and Paranoia.

(trans. Charles Ricksher). Utica, N.Y.: State Hospital Press.

1908. 'Die Prognose der dementia praecox

(Schizophreniegruppe)'. Allgemeine Zeitschrift für Psychiatrie:

436-464.

1911. Dementia Praecox oder Gruppe der Schizophrenien.

Leipzig und Wien: Franz Deuticke.

Donn, Linda. 1988. Freud and Jung: Years of Friendship, Years of Loss.

New York: Charles Scribner's Sons.

Eliade, Mircea. 1977[1952]. 'Eliade's interview for “Combat” 1952'. In

William McGuire and Richard Hull (eds.). C.G. Jung Speaking:

Interviews and Encounters. Princeton: Princeton University Press.

Bollingen series XCVII.

Ellenberger, Henri. 1964. 'La Notion de maladie créatrice'. Dialogue 3: 25-41.

1994[1970]. The Discovery of the Unconscious: The History and Evolution of Dynamic Psychiatry. London: Fontana Press.

Elms, Alan. 2005. 'Jung's Lives.' Journal of the History of the Behavioral Sciences 41 (4): 331-346.

Escamilla, Michael. 2016. Bleuler, Jung, and the Creation of

Schizophrenias. Einsiedeln: Daimon Verlag.

Hannah, Barbara. 1991[1976]. C.G. Jung: His Life and Work. A

Biographical Memoir. Boston: Shambala.

Healy, Nan S. 2017. Toni Wolff \& C.G. Jung. A Collaboration. Los

Angeles: Tiberius Press.

Jaffé, Aniela. 1989[1971]. From the Life and Work of C. G. Jung.

Einsiedeln: Daimon Verlag.

- Protocols of Aniela Jaffé's Interviews with Jung for Memories, Dreams, Reflections. Library of Congress, Washington D.C. (original in German).

Jung, C.G. 1983[1902]. On the Psychology and Pathology of So-Called Occult Phenomena. Collected Works of C. G. Jung. vol. 3, §§1-150. 
- 1982[1908]. The Content of Psychoses. Collected Works of C. G. Jung. vol. 3, §§317-387.

—. 1997[1912a]. Wandlungen und Symbole der Libido. München: Dtv.

1917[1912b]. Psychology of the Unconscious. A Study of the Transformations and Symbolisms of the Libido. A Contribution to the History of the Evolution of Thought. Beatrice M. Hinckle (trans.). New York: Moffat, Yard and Company.

1972[1916]. The Structure of the Unconscious. Collected Works of C. G. Jung. Vol. 7, §§442-521. 1976[1921]. Psychological Types. Collected Works of C. G. Jung. vol. 6 .

1970[1929]. Commentary on "The Secret of the Golden Flower". In Sir Herbert Read, Michael Fordham, Gerhard Adler \& William McGuire (Eds.), Richard Hull (Trans.) Collected Works, Volume 13. London/Princeton: Bollingen Series, Princeton University Press. 1935. 'Über die Archetypen des kollektiven Unbewußten.' In Eranos-Jahrbuch 1934. Zürich: Rhein-Verlag.

. 1977[1955-1956]. Mysterium Coniunctionis. Collected Works of C. G. Jung. Vol. 14. 1975[1957]. The Transcendent Function. Collected Works of C.G. Jung. Vol. 8, §§ 131-193. 1976[1970]. Adaptation, Individuation, Collectivity. Collected Works of C. G. Jung. vol. 18.

- 2009. The Red Book. Liber Novus, edited and introduced by Sonu Shamdasani. New York: Norton \& Company.

- 2012[1989]. Notes of the Seminar on Analytical Psychology given in 1925 by C.G. Jung. Original Edition edited by William McGuire, Revised Edition edited by Sonu Shamdasani. Princeton: Princeton University Press.

- 2013. The Question of Psychological Types. The Correspondence of C. G. Jung and Hans Schmid-Guisan, 1915-1916. John Beebe and Ernst Falzeder (eds.). Princeton and Oxford: Princeton University Press.

Jung, Carl Gustav / Jaffé, Aniela. 2005[1962a]. Erinnerungen, Träume, 
Gedanke. Düsseldorf und Zürich: Walter Verlag. .1989[1962b]. Memories, Dreams, Reflections. New York: Vintage Books.

Kraepelin, Emil. 1896. Psychiatrie: Ein Lehrbuch für Studirende und Aerzte. Leipzig: Verlag von Johann Ambrosius Barth.

Maillard, Christine. 2002. 'Le « Livre de Madame Jaffé» Ma vie de C.G. Jung: remémoration, légitimation, monumentalisation'. Cahiers jungiens de psychanalyse 104 (2):79-97.

- 2017. Au Cour du Livre Rouge. Les Sept Sermons aux morts. Aux sources de la pensée de C.G. Jung. Paris: Éditions Imago.

Noll, Richard. 1994. The Jung Cult: The Origins of a Charismatic Movement. Princeton: Princeton University Press.

- 1997. The Aryan Christ: The Secret Life of Carl Jung. New York: Random House.

Satinover, Jeffrey. 1986. 'Jung's Lost Contribution to the Dilemma of Narcissism.' Journal of the American Psychoanalytical Association 34 (2): 401-438.

Sedgwick, David. 2009. 'Un rêve de Winnicott : réflexions sur Jung et Winnicott.' Cahiers jungiens de psychanalyse 129 (2): 81-100.

Shamdasani, Sonu. 2003[1995]. 'Memories, Dreams, Omissions.' In Paul Bishop (ed.). Jung in Contexts. A Reader. London: Taylor \& Francis e-Library.

- 2005. Jung Stripped Bare by His Biographers, Even. London and New York: Karnac Books.

and Mikkel Borch-Jacobsen. 2006. Le dossier Freud: Enquête sur l'Histoire de la Psychanalyse. Paris: Les Empêcheurs de Tourner en Rond.

2009. 'Liber Novus: The "Red Book" of C.G. Jung.' In The Red Book. Liber Novus, edited and introduced by Sonu Shamdasani. New York: Norton \& Company.

and Mikkel Borch-Jacobsen. 2012. The Freud Files: An Inquiry into the History of Psychoanalysis. Cambridge: Cambridge University Press.

2012. 'Introduction'. In Notes of the Seminar on Analytical Psychology given in 1925 by C.G. Jung. Original Edition edited by 
William McGuire, Revised Edition edited by Sonu Shamdasani. Princeton: Princeton University Press.

Spillmann, Brigitte and Robert Strubel. 2010. C.G. Jung-Zerrissen zwischen Mythos und Wirklichkeit. Über die Folgen persönlicher und kollektiver Spaltungen im tiefenpsychologischen Erbe. Gießen: Psychosozial-Verlag.

Stern, Paul. 1976. C. G. Jung: The Haunted Prophet. New York: George Braziller.

Swan, Wendy. 2006. 'Tina Keller's Analyses with C. G. Jung and Toni Wolff, 1915-1928'. Journal of Analytical Psychology 51: 493-511.

Wehr, Gerhard. 1988[1985]. Jung: Leben, Werk, Wirkung. Zurich: Diogenes Verlag.

Winnicott, Donald Woods. 1964. 'Memories, Dreams, Reflections by C. G. Jung'. International Journal of Psychoanalysis 45: 450-455. 